\title{
A SIMULATION TEMPLATE FOR MODELING TUNNEL SHAFT CONSTRUCTION
}

\author{
Fangyi Zhou \\ S.M.A. Consulting Ltd. \\ 305 Meadowlark Professional Building \\ Edmonton, AB T5R 5W5, CANADA \\ Simaan M. AbouRizk \\ Dept. of Civil and Environmental \\ Engineering \\ 3-014 Markin/CNRL Natural \\ Resources Engineering \\ Facility, University of Alberta \\ Edmonton, AB T6G 2M7, CANADA
}

\author{
Siri Fernando \\ City of Edmonton Asset Management \\ and Public Works, Drainage Services \\ 9803 102A Avenue
}

Edmonton, AB T5J 3A3, CANADA

\begin{abstract}
This paper presents the design and development of a template for analyzing shaft construction projects. It is suitable for integration with the existing Tunneling template of the Simphony modeling environment to provide users a complete, functional and more flexible simulation tool for tunnel construction. The developed system will be a powerful tool for decision-making and evaluating the feasibility of tunnel construction methods, in identifying and allocating site spaces, and in the visualization of tunneling construction sites as a mean of describing the site layout to other involved parties. Further, it assists users in modeling several scenarios without changing the developer's code or the base of the tool, and it does not require integration with any other modeling templates. This template design is then applied to a case study involving the construction of a circular tunnel shaft, part of the North Edmonton Sanitary Tunneling (NEST) system in Edmonton, Canada.
\end{abstract}

\section{INTRODUCTION}

Generally, shaft construction involves a number of interrelated operations. The major operations are excavation and primary lining, as well as lowering ground water and secondary lining if required. Figure 1 illustrates the structure of shaft construction strategy.

The shaft construction template described in this paper was developed collaboratively with the City of Edmonton Asset Management and Public Works Department under the NSERC/Alberta Construction Industry Research Program in Construction Engineering and Management at the University of Alberta. The template developed partially aims at optimizing construction site layout; this area of research is detailed elsewhere (see AbouRizk et al. (1999) for development of special purpose simulation templates). The template was designed using the Simphony modeling environment; for a description of this platform as an optimizing technology, see AbouRizk and Mohamed (2002). The use of simulation applications in tunneling overall has been detailed in Fernando et al. (2003). The shaft construction work performed by the City of Edmonton was studied before creating this special purpose simulation (SPS) template.

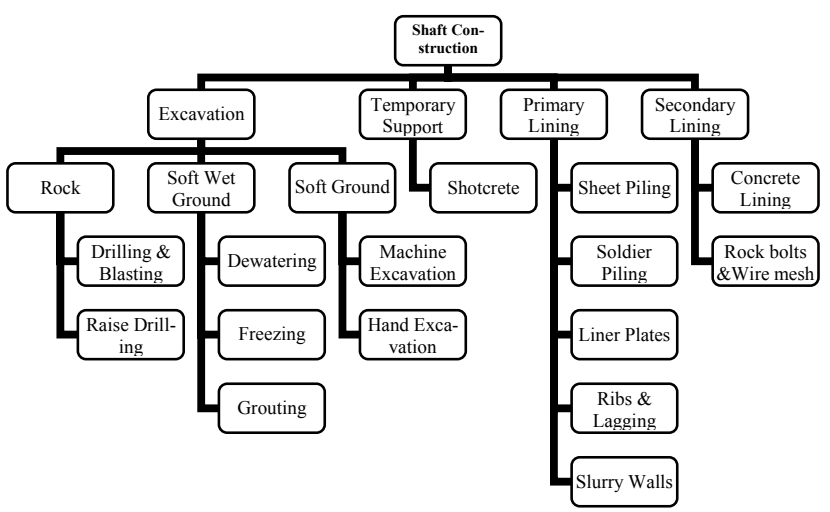

Figure 1: Structure of shaft construction strategy

Shafts are mostly classified as working shafts and retrieval shafts based on function. Working shafts allow for equipment and personnel access and removal of tunnel debris, while retrieval shafts enable the Tunnel Boring Machine (TBM) to be recovered. The City of Edmonton presently sinks four sizes of circular shaft, with diameters of $14 \mathrm{ft} 8$ in $(4.47 \mathrm{~m}), 12 \mathrm{ft}(3.66 \mathrm{~m}), 10 \mathrm{ft}(3.05 \mathrm{~m})$ and 8 $\mathrm{ft}(2.44 \mathrm{~m})$. Excavation and dirt removal is performed by equipments including: augers, cranes, clamshell or bucket excavators, or backhoes.

\section{SHAFT CONSTRUCTION PROCESS}

Circular shaft construction begins with the assembly of shaft liners for different excavation sections. Other typical activities consist of machine drilling, installing shaft liners, hand excavating, installing the safety wall, etc. Typi- 
cal and occasional construction process flows are illustrated in Figure 2.

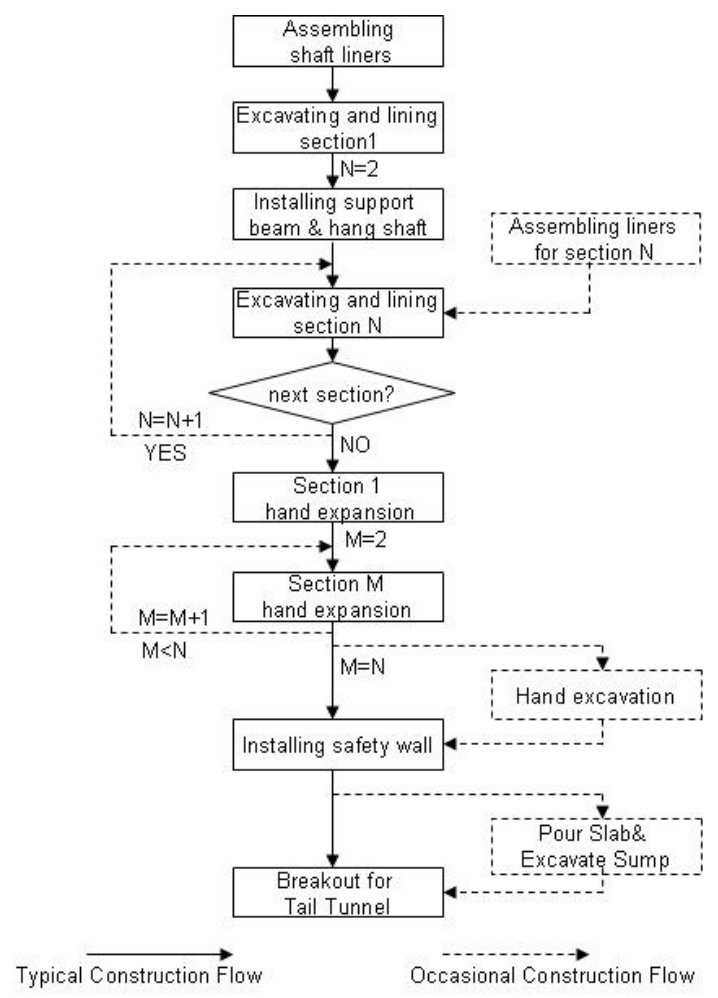

Figure 2: Circular shaft construction process

The major shaft temporary support system utilizes ribs-and-lagging segments. The ribs-and-lagging method has a record of high performance in a variety of ground conditions. Curved steel ring segments are bolted together, with side-by-side timber wedging circumferentially between rings. Ribs-and-lagging segments are prefabricated before excavation, a process which is known as "assembling liner." Assembling liner happens before the corresponding shaft section is excavated, parallel to the activity of excavating the previous shaft section.

Hand excavation is used extensively to enlarge the hole drilled by the flight auger, in deep sections where the TBM cannot excavate, or when excavating tools have limited functionality. Hand expansion progresses outward until the shaft end diameter is achieved.

The base slab is poured to resist uplift by its own weight and anchored into the lining of the shaft; it is normally made watertight by grouting. The shaft base may also have to accommodate various items of the construction plant. In water-bearing ground, a sump is essential for construction to progress (Megaw 1983). A sump, along with pumps, is employed to remove the water entering the shaft after the seal is placed or to prevent water accumulation in low spots during construction, a process which is known as unwatering. Occasionally, a sump also serves for dumping dirt.

\section{TAIL TUNNEL AND UNDERCUT CONSTRUCTION PROCESS}

An undercut is a length of tunnel adjacent to a shaft used for setting up and staging equipment. A tail tunnel is normally located on the opposite side of an undercut and is used to provide room for a train to unload or switch tracks. The construction of a tail tunnel starts with a small opening in the shaft from which a short timbered heading is driven. Table 1 explains the sequence of the typical construction operations shown in Figure 3. The cycle is repeated until the required length is achieved. Excavation and rib-installation of the top sections always happen before the corresponding bottom sections are excavated. The

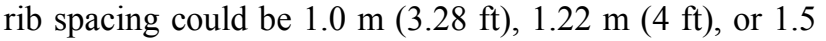

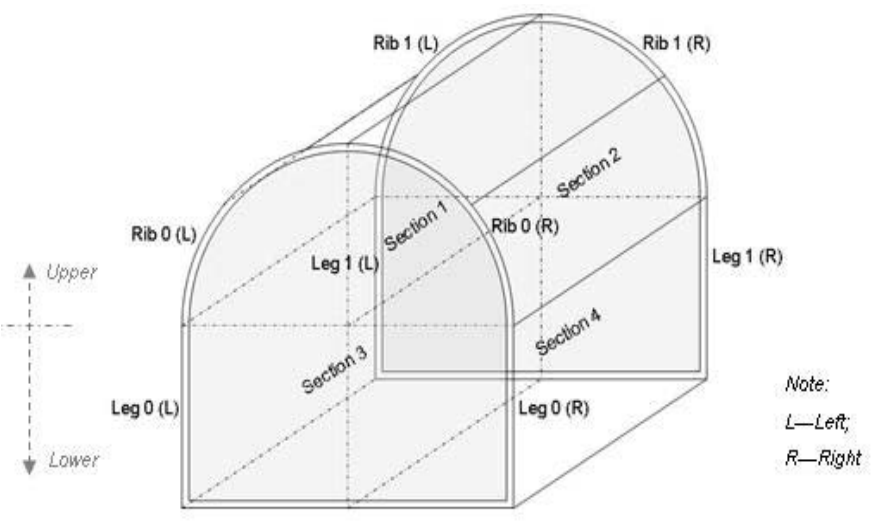

m (4.92 ft).

Figure 3: Tail tunnel/undercut section

Table 1: Sequence of tail tunnel construction activities

\begin{tabular}{|l|c|l|c|}
\hline Operation & Sequence & Operation & Sequence \\
\hline Install rib 0 (L) & 1 & $\begin{array}{l}\text { Install rib for leg } \\
\text { (L) }\end{array}$ & 9 \\
\hline $\begin{array}{l}\text { Excavate section } \\
\text { 1 (U.L.) }\end{array}$ & 2 & $\begin{array}{l}\text { Excavate section } \\
\text { 3 (L.L.) }\end{array}$ & 10 \\
\hline Install rib 1 (L) & 3 & $\begin{array}{l}\text { Install rib for leg } \\
\text { 1 (L) }\end{array}$ & 11 \\
\hline $\begin{array}{l}\text { Install lagging for } \\
\text { section 1 }\end{array}$ & 4 & $\begin{array}{l}\text { Install lagging for } \\
\text { section 3 }\end{array}$ & 12 \\
\hline $\begin{array}{l}\text { Install rib 0 (R) } \\
\text { Excavate section } \\
\text { 2 (U.R.) }\end{array}$ & 6 & $\begin{array}{l}\text { Install rib for leg } \\
\text { (R) }\end{array}$ & $\begin{array}{l}\text { Excavate section } \\
\text { 4 (L.R.) }\end{array}$ \\
\hline $\begin{array}{l}\text { Install rib 1 (R) } \\
\text { Install lagging for } \\
\text { section 2 }\end{array}$ & 8 & $\begin{array}{l}\text { Install rib for leg } \\
\text { 1 (R) }\end{array}$ & $\begin{array}{l}\text { Install lagging for } \\
\text { section 4 }\end{array}$ \\
\hline
\end{tabular}

* Note: U.L.-Upper Left; L.L.-Lower Left; U.R. --Upper Right; L.R.-Lower Right; L-Left; R-Right 
Dirt from the excavation is normally hoisted using clamshells (shallow shafts) or cranes (medium to deep shafts). A gantry hoist or derrick hoist is used occasionally for deep shafts. The construction processes for the undercut and tail tunnel are identical.

\section{PROPOSED SHAFT SIMULATION TEMPLATE}

A tunneling model capable of capturing the complexity of excavating, lining, dirt removing, activity interaction and uncertainty in a tunneling project would be of great value to engineers and planners. Based on simulation platforms currently available and applicability to the area of study, the proposed shaft modeling system would extend the capabilities of the Tunneling template within the Simphony environment to address the unique requirements of modeling the tunneling process as a whole.

As a supplement of the Tunneling template, some of the original template's features are inherited, for the sake of consistency:

- Project Planning. The template tool enables planners to specify the methods and sequence of the construction operations, define the resources required for the operations, and analyze the production of the system before commencing construction.

- Bottlenecks Detection. Detection of potential bottlenecks helps planners and engineers determine corrective measures before commencing construction.

- Scenarios Comparison. Simulation allows users to predict productivity and compare the outputs of different scenarios; this enables planners to make informed decisions before embarking on the project.

Enhanced features include:

- Extendibility. The proposed template can be easily extended to accommodate more policies, more disciplines, more strategies, and more advanced outputs in simulation blocks.

- Compatibility. The proposed simulation setting is compatible with other developed simulation templates for construction processes and other applications.

\section{SIMPHONY SHAFT MODELING ELEMENTS AND FUNCTIONS}

The template for shaft construction was implemented in Simphony (AbouRizk and Hajjar 2002). Various shaft construction equipment, labor disciplines, and material handing systems were studied systematically to extract the modeling elements for the template. The proposed SPS template for shaft construction comprises 11 model- ing elements, with the graphical representations demonstrated in Figure 4. This section reviews the characteristics and functions of these elements.

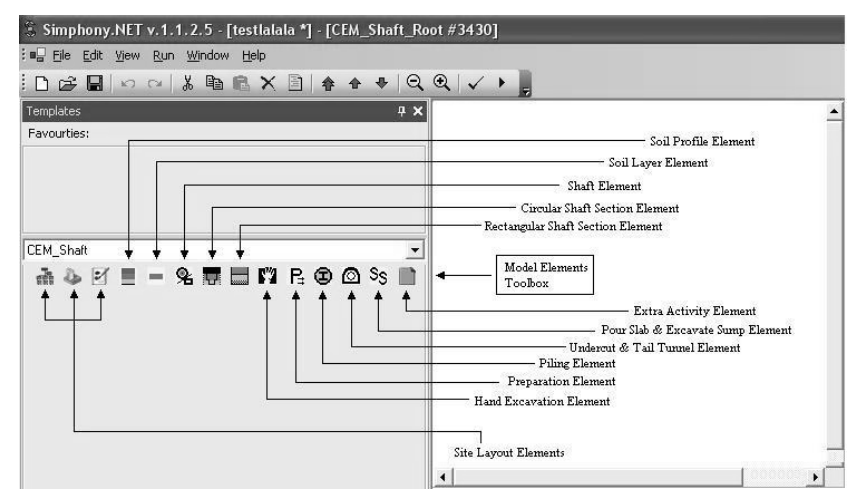

Figure 4: Shaft template elements

\subsection{Shaft Element}

The Shaft element is a parent element designed to encompass all other elements that are shaft-construction-related in the template (see Figure 5). Its inputs include "description", "shaft depth," "shaft length (for rectangular shaft)," "shaft end diameter," "shaft width (for rectangular shaft)," "shift length," "daily number of shifts," and "shaft shape."

When "circular" is chosen as the "shaft shape," "shaft end diameter" with a default value appears as its specific parameter, and all child elements to be created are limited to common-use or circular shaft use only. On the other hand, by choosing "rectangular," the corresponding parameters are automatically added or deleted. Consequently, users are allowed to create child elements developed for common-use or for rectangular shaft only. As well, the element appearance is updated in connection with the shape selected.

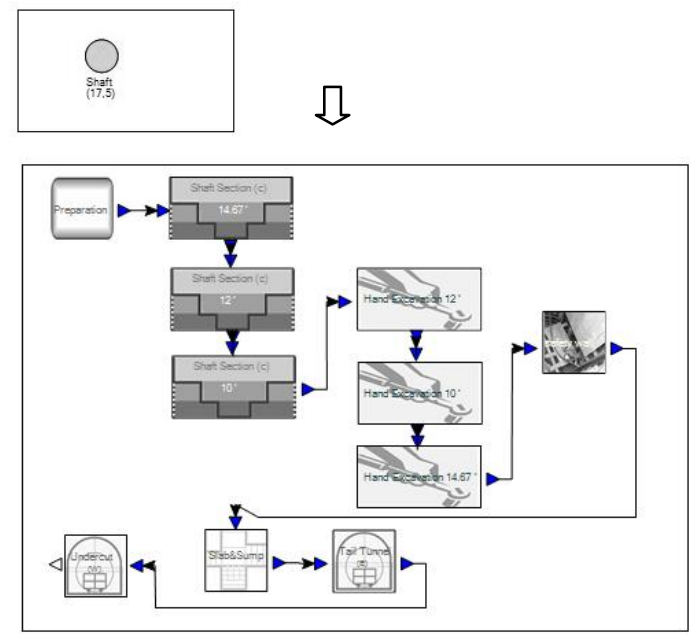

Figure 5: Circular Shaft element and layout of child window 
The output of the element is "Dirt Amount from Construction", exhibiting the amount of dirt accumulated by excavating the shaft, sump, undercut, and/or tail tunnel. Based on the soil information users provide, the system calculates the muck removed from each operation and accumulates the total. This facilitates decision making in the area required for spoil pile.

The statistics "Shaft Construction Duration" provides the record of the construction duration of the project, including that for shaft, sump, undercut, and/or tail tunnel.

\subsection{Soil Profile Element}

The Soil Profile element (see Figure 6) was designed to function as the soil information source for the whole model. All elements representing shaft construction operations read penetration rate and soil swell factor from this element and its child elements. The element is to be created in the same level as the "Shaft" element; and existence of more than one "Shaft Profile" is not allowed in the same model. When the number of test holes on site is more than one, users would have to select the one closest to the shaft and input the soil information. This element allows users to input "number of layers".

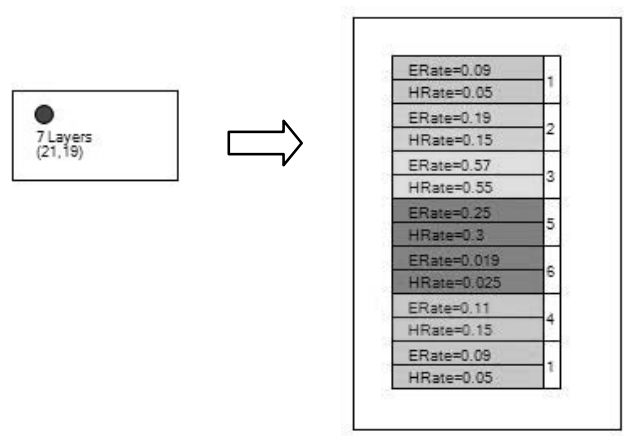

Figure 6: Soil profile element and layout of child window

\subsection{Soil Layer Element}

Several "Soil Layer" elements are created automatically in the child window of the "Shaft Profile" element. The number of creations equals the layer value assigned by the users for its parent element. Users are not requested to add or delete any of them. Five input parameters are comprised of "soil type", "layer thickness", "excavation rate (by machine)", "excavation rate (by hand)", "sequence of the layer", and "soil swell factor of the layer".

Even after being created, the elements are also automatically added and deleted in connection with the parameter "Number of Layers" of the Soil Layer element.

\subsection{Preparation Element}

The Preparation element is developed as a child of the Shaft element only. This element serves as the start of any shaft models: it creates entities and transfers them out. Due to the fact that site preparation or assembling liners are necessary for any real project, "Preparation" was set to be a functional element, and a model without this element is incomplete.

\subsection{Circular Shaft Section Element}

The Circular Shaft Section element is designed specially to simulate the circular shaft section patterns. It is a functional element that is required by all circular shaft models. During modeling, more than one element is created, each of which stands for operations such as excavating and lining for one section, as shown in Figure 7. The Circular Shaft Section elements, in company with the Hand Excavation elements, are the main components of a circular shaft model.

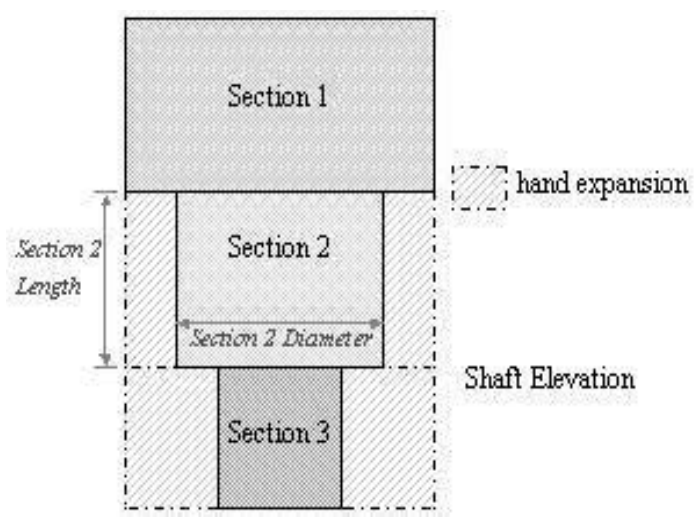

Figure 7: Circular shaft sections

This element contains four parameters, allowing users to input "section length", "section diameter", "duration for assembling liner", and "duration for installing beam and hang shaft".

Some hidden attributes were added to link with the Soil Layer elements and to induct the penetration rate and swell factor for different soil conditions from them. Any soil layer that has fully or partially finished excavating and lining is marked correspondingly. Each of the Circular Shaft Section elements created employs the soil information from the first unfinished layer and continues to the successive layers, or passes the entity to the next element if desired. This element has "amount of dirt generated" as its output and "section cycle time" as the statistic. 


\subsection{Hand Excavation Element}

The Hand Excavation element is common to circular and rectangular shaft construction. It may represent hand expansion of certain circular shaft sections excavated by machines to the shaft end dimension, excavating and lining circular shaft where machines are limited by geology or depth, or excavating and installing walers for a rectangular shaft. Similar to the Circular Shaft Section and Rectangular Shaft Section elements, the entity starts working from the first fully or partially un-excavated soil layer.

For a circular shaft, this element initiates a search for the corresponding Circular Shaft section and calculates dirt amount afterwards. An illustration of the operating process is shown in Figure 8.

Two input parameters are included in this element: "section length" and "section diameter." Users need not pay attention to "section diameter" when creating a model for a rectangular shaft. The output "duration" refers to the time required for the operation of the section represented by the element.

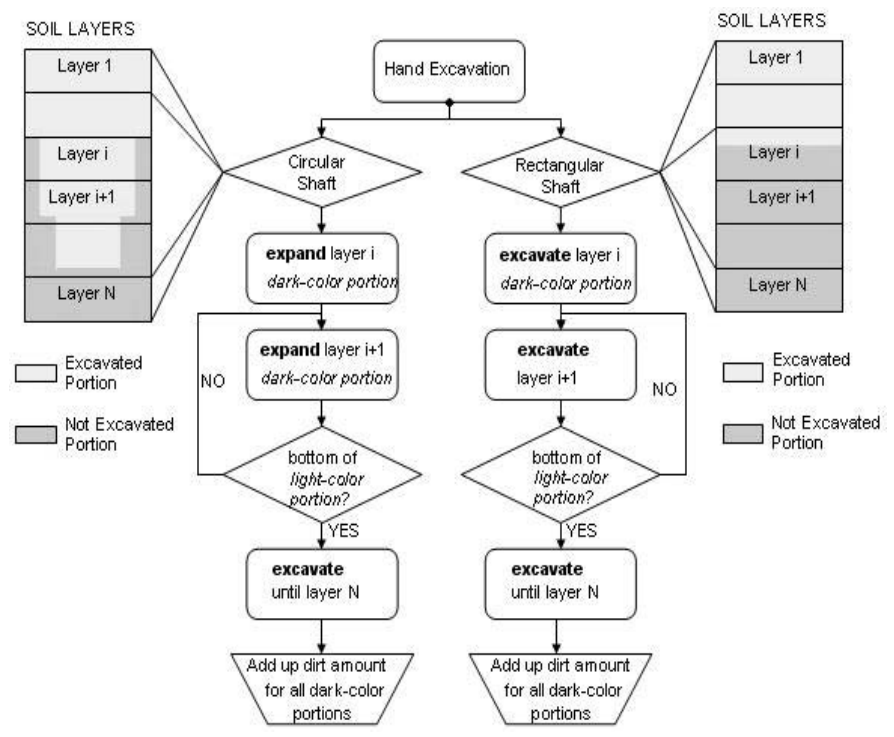

Figure 8: Hand excavation process

\subsection{Slab \& Sump Element}

The Slab \& Sump element simulates the process of excavating sump and pouring slab. It has five parameters, all of which assist the system in calculating the "dirt amount from excavating sump" and "duration" outputs of the element.

\subsection{Extra Activity Element}

The Extra Activity element represents any construction activity that is not covered by the other elements, such as constructing a safety wall.

\subsection{Tail Tunnel Element}

The Tail Tunnel element was developed for simulating either the tail tunnel or the undercut.

One or more Tail Tunnel elements can be created in a simulation model to represent the tail tunnel/undercut construction process in different directions, corresponding to the parameter "Direction." Tail tunnel/Undercut construction normally commences with a two-day-breakout, followed by step-by-step openings along with ribs and lagging as the primary support. The duration for excavation and lining is calculated backstage.

\section{CASE STUDY}

The case study tests the functionality and usability of the Shaft construction template in application to a real circular shaft tunneling project. The study tests the template for shaft and undercut construction stage, comparing the simulation results such as project construction duration with those provided by the project engineers. It also evaluates two alternatives at the project planning stage of the studied project with respect to shaft construction.

\subsection{Problem Statement}

The selected project is part of the NEST (North Edmonton Sanitary Tunneling) system undertaken by the City of Edmonton. The section considered is a new $2.3 \mathrm{~m}$ diameter tunnel with total length of $3707 \mathrm{~m}$ from 76 Street to Manning Drive, running along 153 Avenue in Edmonton, with an overflow weir structure connecting the existing NL1 pump station and NL2. An overview of the tunneling site adjacent area is shown in Figure 9.

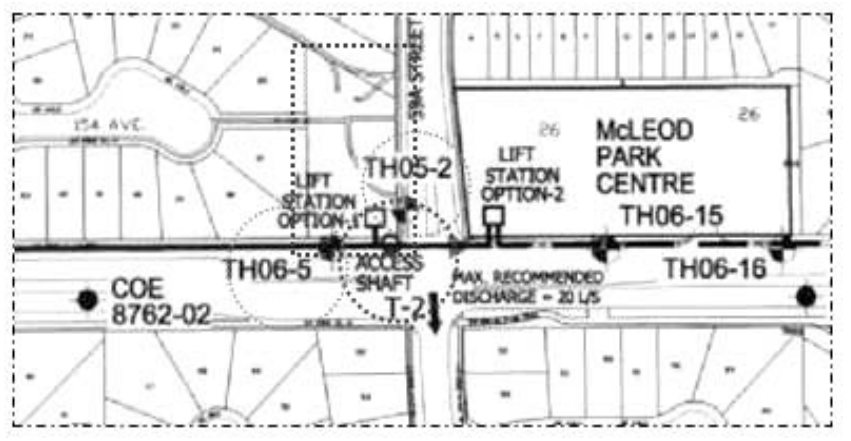

Figure 9: Overview of NEST NL-1/NL-2 project site 
The working shaft of the project is set up at the position shown in Figure 9. Its end diameter is the standard 14 $\mathrm{ft} 8$ in $(4.47 \mathrm{~m}$, with rib and lagging support) and its depth is $33 \mathrm{~m}(108.27 \mathrm{ft})$. A soil log report was obtained from City of Edmonton, with the information of the two closest test holes to the working shaft, TH05-2 and TH06-5. (The relative position of TH05-2 and TH06-5 from the shaft can be seen from Figure 9.) The boreholes reveal that the shaft will be built mainly in bedrock, encountering four primary soil categories, namely Top Soil/Fill, Clay, Bedrock, and Coal.

The primary shaft construction activities are comprised of assembling shaft liners for the entire shaft, drilling three sections with standard sizes and installing liners, as well as the activities for standard shaft construction for utility tunneling at the City of Edmonton (refer to Figures 7 and 8). Two-way undercuts are required as part of the shaft construction, one of which partially functions as a tail tunnel for temporarily storing equipments and liners.

\subsection{Simulation Model}

In mapping the NEST NL1-NL2 Project construction site onto the Simphony interface, the modeling system starts with generating the tunneling site and objects. Site boundaries are created firstly, appearing simultaneously with the shaft and test hole.

An 8 hour-shift per day is employed in constructing shaft and undercut. A shaft construction model is presented in Figures 10 and 11, generated as the child windows of the Shaft element and the Soil Profile element, respectively. The input information is provided in Table 2.

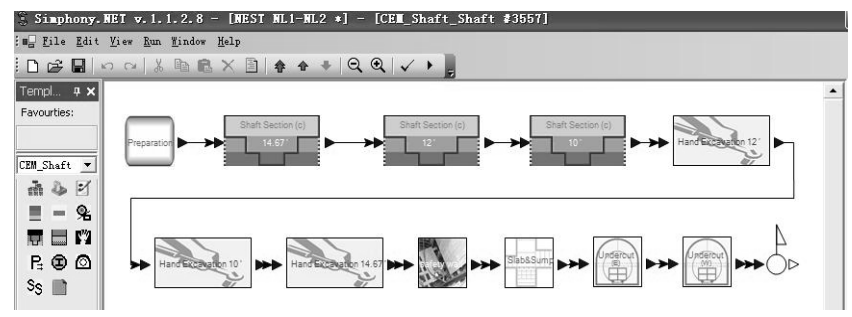

Figure 10: Child window of Shaft element — shaft construction model

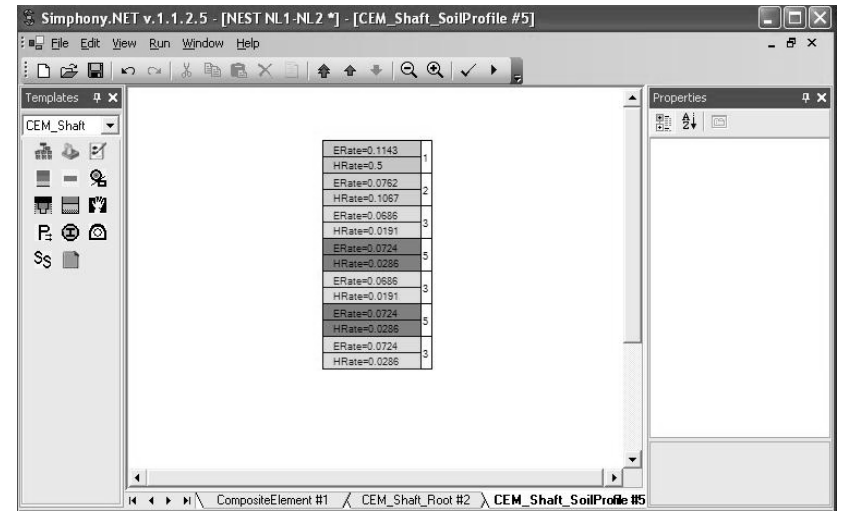

Figure 11: Child window of "Soil Profile" element—shaft construction model

Table 2: Input information for shaft construction model

\begin{tabular}{|c|c|c|c|c|}
\hline Element & $\begin{array}{c}\text { Input Pa- } \\
\text { rameter }\end{array}$ & Value & $\begin{array}{l}\text { Input Pa- } \\
\text { rameter }\end{array}$ & Value \\
\hline Preparation & Duration & $\begin{array}{l}\text { Constant } \\
\text { (1) day }\end{array}$ & & \\
\hline $\begin{array}{c}\text { Circular } \\
\text { Shaft Sec- } \\
\text { tion }\left(14.67^{\prime}\right)\end{array}$ & $\begin{array}{l}\text { Duration for } \\
\text { installing } \\
\text { beam and } \\
\text { hang shaft }\end{array}$ & $\begin{array}{c}\text { Constant } \\
\text { (1) } \\
\text { day }\end{array}$ & $\begin{array}{c}\text { Segment } \\
\text { depth }\end{array}$ & $\begin{array}{c}9.75 \mathrm{~m} \\
(31.99 \mathrm{ft})\end{array}$ \\
\hline $\begin{array}{l}\text { Circular } \\
\text { Shaft Sec- } \\
\text { tion (12') }\end{array}$ & $\begin{array}{c}\text { Segment } \\
\text { length }\end{array}$ & $\begin{array}{c}9.75 \mathrm{~m} \\
(31.99 \mathrm{ft})\end{array}$ & & \\
\hline $\begin{array}{l}\text { Circular } \\
\text { Shaft Sec- } \\
\text { tion }\left(10^{\prime}\right)\end{array}$ & $\begin{array}{l}\text { Segment } \\
\text { length }\end{array}$ & $\begin{array}{c}5.5 \mathrm{~m} \\
(18.04 \mathrm{ft})\end{array}$ & & \\
\hline $\begin{array}{l}\text { Hand Exca- } \\
\text { vation }\end{array}$ & $\begin{array}{c}\text { Segment } \\
\text { length }\end{array}$ & $\begin{array}{c}9.75 \mathrm{~m} \\
(31.99 \mathrm{ft})\end{array}$ & $\begin{array}{l}\text { Segment di- } \\
\text { ameter }\end{array}$ & $\begin{array}{c}12 \mathrm{ft} \\
(3.66 \mathrm{~m})\end{array}$ \\
\hline $\begin{array}{l}\text { Hand Exca- } \\
\text { vation }\end{array}$ & $\begin{array}{l}\text { Segment } \\
\text { length }\end{array}$ & $\begin{array}{c}5.5 \mathrm{~m} \\
(18.04 \mathrm{ft})\end{array}$ & $\begin{array}{l}\text { Segment di- } \\
\text { ameter }\end{array}$ & $\begin{array}{c}10 \mathrm{ft} \\
(32.81 \mathrm{ft})\end{array}$ \\
\hline $\begin{array}{l}\text { Hand Exca- } \\
\text { vation }\end{array}$ & $\begin{array}{l}\text { Segment } \\
\text { length }\end{array}$ & $\begin{array}{c}8 \mathrm{~m} \\
(26.25 \mathrm{ft})\end{array}$ & $\begin{array}{l}\text { Segment di- } \\
\text { ameter }\end{array}$ & $\begin{array}{c}14.67 \mathrm{ft} \\
(4.47 \mathrm{~m})\end{array}$ \\
\hline Safety Wall & Duration & $\begin{array}{l}\text { Constant } \\
\text { (2) day }\end{array}$ & & \\
\hline Slab \& & $\begin{array}{l}\text { Duration for } \\
\text { excavating } \\
\text { sump }\end{array}$ & $\begin{array}{l}\text { Constant } \\
\text { (2) day }\end{array}$ & $\begin{array}{l}\text { Duration for } \\
\text { pouring slab }\end{array}$ & $\begin{array}{l}\text { Constant } \\
\text { (2) day }\end{array}$ \\
\hline Sump & $\begin{array}{l}\text { Diameter of } \\
\text { the sump }\end{array}$ & $\begin{array}{c}2.2 \mathrm{~m} \\
(7.22 \mathrm{ft})\end{array}$ & $\begin{array}{l}\text { Depth of the } \\
\text { sump }\end{array}$ & $\begin{array}{l}2.75 \mathrm{~m} \\
(9.02 \mathrm{ft})\end{array}$ \\
\hline $\begin{array}{l}\text { Undercut } \\
\text { (E) }\end{array}$ & Swell Factor & 1.8 & & \\
\hline \multirow{3}{*}{$\begin{array}{l}\text { Undercut } \\
\text { (W) }\end{array}$} & $\begin{array}{l}\text { Undercut } \\
\text { length }\end{array}$ & $\begin{array}{c}24 \mathrm{~m} \\
(72.74 \mathrm{ft})\end{array}$ & $\begin{array}{c}\text { Section } 1 \\
\text { length }\end{array}$ & $\begin{array}{c}6.765 \mathrm{~m} \\
(22.19 \mathrm{ft})\end{array}$ \\
\hline & Direction & W & $\begin{array}{c}\text { Section } 2 \\
\text { length }\end{array}$ & $\begin{array}{c}15 \mathrm{~m} \\
(49.21 \mathrm{ft})\end{array}$ \\
\hline & $\begin{array}{c}\text { Section } 0 \\
\text { length }\end{array}$ & $\begin{array}{l}2.235 \mathrm{~m} \\
(7.33 \mathrm{ft})\end{array}$ & & \\
\hline
\end{tabular}


Simulation results show that a mean value of 71.8 days is required to construct the shaft and undercut area, while the duration estimated by project planners is 69 days based on an 8 hours shift per day. Analysis of the simulation result shows that the project is mainly delayed by hand excavation, which is unavoidable due to the thick bedrock layer in the shaft adjacent area. A total dirt amount of $1095 \mathrm{~m}^{3}$ could be accumulated from the excavation.

This output helps with deciding the area kept for spoil pile on the construction site, and helps with analyzing in order to further control the frequency of dirt removal truck's arrival.

\section{CONCLUSIONS}

This paper establishes the functionality and usability of a proposed Shaft construction template for an integrated modeling system developed. Extending the existing tunneling template is a significant step towards a revised and completed tunneling template in the future. The presented modeling system primarily enables users to test the validity of shaft construction planning strategies, and (although not discussed here) to evaluate various site layout options.

A case example of an actual project from City of Edmonton, the North Edmonton Sanitary Tunneling System (NEST) NL1-NL2, was analyzed using the developed modeling system. The analysis of shaft modeling result shows that the simulation system can be very useful in predicting and evaluating shaft construction duration of various options. The developed system provides a powerful tool to engineers and project managers in evaluating the feasibility of tunnel construction methods, in identifying and allocating site spaces, and in the visualization of tunneling construction sites to describe the site layout to other involved parties, all of which are valuable decisionmaking supports.

\section{REFERENCES}

AbouRizk, S. M. and Y. Mohamed. 2002. Optimal construction project planning. Proceedings of the 2002 Winter Simulation Conference, 1704-1708.

AbouRizk, S. M., J. Y. Ruwanpura,, K. C. Er, S. Fernando. 1999. Special Purpose Simulation Template for Utility Tunnel Construction. Proceedings of the 1999 Winter Simulation Conference, 948-955.

Hajjar, D. and S. M. AbouRizk. 2002. Unified Modeling Methodology for Construction Simulation. Journal of Construction Engineering and Management, ASCE, New York, New York, 128(2): 174-185.

Fernando, S., K.C. Er, Y. Mohamed, S. AbouRizk, and J.Y. Ruwanpura. 2003. A Review of Simulation Applications for Varying Demands in Tunneling. Pro- ceedings of the 2003 ASCE Construction Research Congress.

Megaw, T. M., and J. V. Bartlett. 1983. Shafts and Caissons. Tunnels: Planning, Design, Construction, International Edition, Ellis Horwood Limited, John Wiley and Sons, New York. 